\title{
Seasonal Variation in Body Condition of Adult Barents Sea Harp Seals (Phoca groenlandica)
}

\author{
K. T. Nilssen and T. Haug \\ Norwegian Institute of Fisheries and Aquaculture \\ N-9005 Tromsø, Norway \\ P. E. Grotnes \\ Norwegian College of Fisheries Science \\ University of Troms $\varnothing$, N-9037 Troms $\varnothing$, Norway \\ and \\ V. Potelov \\ Polar Research Institute of Marine Fisheries and Oceanography (PINRO) \\ 6 Knipovich Street, 183763, Murmansk, Russia
}

\begin{abstract}
In the period 1990-94, harp seals (Phoca groenlandica) were sampled for ecological studies in various areas and seasons in the Barents Sea. Data on total body weight, standard body length, axillary girth, dorsal and ventral blubber thickness were collected from all seals. Data from seals with standard body length $150 \mathrm{~cm}$ or more were analysed in order to evaluate the seasonal dynamics in body condition of the adult seals. Blubber thickness measurements and a condition index $(C)$ expressed as $C=\sqrt{L / W} \times d$, where $L$ is standard body length $(\mathrm{cm}), W$ is total body mass $(\mathrm{kg})$ and $\mathrm{d}$ is dorsal blubber thickness $(\mathrm{cm})$, showed the same seasonal patterns. The seals were in poor condition in spring and early summer (May-June), condition improved during the course of summer, and the animals were in good condition in September and in October when the mean dorsal blubber thickness was approximately $88 \mathrm{~mm}$. The energy stores built up during the summer and autumn were maintained until February, whereafter the seals became thinner as the stores of blubber decreased rapidly during the breeding season (late February-March). A slight, but not significant increase in dorsal blubber thickness was observed in the short period between lactation and moult (late March-early April), but the stores of blubber decreased further during moult (late April-May) to a mean dorsal blubber thickness of less than $20 \mathrm{~mm}$ in mid-June. No significant difference was observed in blubber thickness or condition indices between the sexes in the various periods, except during April when the females were in significantly poorer condition than the males. Harp seals sampled during the seal invasions to North Norwegian coastal waters in February 1988 were in poorer condition than seals captured in the Barents Sea in February 1993.
\end{abstract}

Key words: Barents Sea, body condition variations, harp seals.

\section{Introduction}

In phocid seals and cetaceans, the subdermal fat tissue, the blubber layer, is important for thermal insulation, serves as buoyancy and to streamline the body, and also serves as an energy reservoir (Scholander et al., 1950; Pond, 1978; Worthy and Lavigne, 1987; Ryg et al., 1988). The relative amount of fat stored in the blubber layer and in the core of the animals (muscle, skeleton and viscera) varies between marine mammal species (Worthy and Lavigne, 1987). The energy reserves also vary in conjunction with the reproductive cycle, migrations and food availability (Sergeant, 1973; 1991; Pitcher, 1986; Fedak and Andersen, 1987; Ryg et al., 1990). In marine mammals the level of fat reserves, which is mainly the blubber layer, has been considered the best indication of body condition and energetic status (Lockyer, 1986; Read, 1990; Ryg et al.,1990). 
In harp seals (Phoca groenlandica), most studies of body condition have been carried out during the reproduction period (Worthy and Lavigne, 1983a, b; 1987; Stewart and Lavigne, 1984; Worthy, 1987; Kovacs et al., 1991), although some studies have been carried out in the Northwest Atlantic in other periods (Sergeant, 1973; 1991; Beck et al., 1993; Chabot et al., MS 1995) and on captive animals (Renouf et al., 1993). In the Barents Sea area earlier studies of harp seal condition have been carried out only during spring, including both breeding, between breeding and moult, and moulting periods (Sivertsen, 1941).

In 1978 the Barents Sea harp seal stock was estimated to comprise approximately 800000 animals and increasing, with 170000 pups being born annually (Benjaminsen, 1979). During the 1980 s, however, some decrease in rates of recruitment to the stock may have occurred (Anon., MS 1992; MS 1994; Kjellqwist et al., 1995). Nevertheless, the harp seal is the most abundant seal species and an important predator in the Barents Sea. The species is now included in a multispecies model (MULTSPEC), which may provide the basis for future management of marine resources in the Barents Sea (Bogstad et al., MS 1995). The annual migration pattern of Barents Sea harp seals is usually characterized by a north-bound feeding migration in spring and summer and a south-bound breeding migration during winter (Haug et al., 1994). Summer and autumn, and probably also early winter seem to be the most intensive feeding periods for this population (Lydersen et al., 1991; Nilssen et al., MS 1994; 1995a,b).

Data describing the variations in condition of the harp seals through the year are necessary prerequisites when the annual consumption of various prey species by the seal stock is to be estimated. From 1990-1994, harp seals were sampled for ecological studies in various areas and seasons in the Barents Sea (Nilssen et al., MS 1994; 1995a,b; Nilssen, 1995). Some preliminary information on harp seal condition variation has been reported previously (Nilssen, 1995). The purpose of the present study was to select data from all adult seals for evaluations of seasonal variation in body condition. Blubber thickness measurements of these animals were also compared to that of harp seals sampled during the seal invasions to North Norwegian coastal waters in 1988 (Haug et al., 1991; Nilssen et al., 1992).

\section{Materials and Methods}

\section{Sampling}

In winter and spring, data were collected in the southern parts of the Barents Sea, in the White Sea and at the northeastern coast of North Norway. A survey designed to collect biological material from harp seals in the areas between Cape Kanin and Novaya Zemlya was conducted in February 1993 (Nilssen et al., MS 1994). Between breeding and moult, in the last week of March and the first week of April 1992, harp seals were either shot or collected from by-catches in gill net cod-fisheries in Varangerfjord, North Norway (Nilssen et al., 1995a). In the moulting period, data were collected from seals taken during Norwegian commercial sealing in the southern parts of the Barents Sea (the "East Ice") in April 1992 (Nilssen et al., 1995a), and from seals taken during Russian scientific sealing in the White Sea in May 1994 (Table 1; Fig. 1).

During the summer period, a harp seal survey was carried out along the edge of the drifting packice between Novaya Zemlya and Hopen in June 1991, and seals were sampled southeast of Hopen (Table 1; Fig. 1). Some of these seals were in their latest stages of moult as late as mid-June (Nilssen et al., 1995b).

During autumn, surveys were conducted in the harp seal feeding areas in the northernmost parts of the Barents Sea in September 1990 and 1991, and in October 1992 (Nilssen et al.,1995b) (Table 1; Fig. 1).

Data were obtained from harp seals taken as bycatches in gill net cod-fisheries at the coast of North Norway in February and June 1988 (Table 1; Fig. 1).

\section{Measurements}

Data from all seals with standard body length $150 \mathrm{~cm}$ or more were selected for evaluations of seasonal variation in body condition. At this body size most seals will probably have attained sexual maturity (Kjellqwist et al., 1995).

Seals were weighed to the nearest $\mathrm{kg}$ in all sampling periods except in June 1988 and in May 1994 where no body weights $(W)$ were obtained (Table 1). No corrections were made for the weight of stomach contents or foetus, or for the weight of 
TABLE 1. Summary of adult harp seals $(>150 \mathrm{~cm})$ used for the present study of body condition. The seals were selected from Barents Sea harp seals sampled for ecological studies in the period 1988-94 (see Nilssen, 1995). CS = commercial sealing; $\mathrm{SE}=$ scientific expeditition; $\mathrm{GN}=$ gill net by-catches. The numbers in parenthesis indicate the sampling areas shown in Fig. 1.

\begin{tabular}{lllcc}
\hline \hline Year & Season & \multicolumn{1}{c}{ Area } & $\begin{array}{c}\text { Sampling } \\
\text { type }\end{array}$ & $\begin{array}{c}\text { No. of } \\
\text { Seals }\end{array}$ \\
\hline 1988 & Feb/Jun & Coast of North Norway (8) & GN & $14 / 60$ \\
1990 & Sep & East of Svalbard (5) & SE & 18 \\
1991 & Jun & East of Hopen (4) & SE & 61 \\
1991 & Sep & East of Svalbard (6) & SE & 23 \\
1992 & Mar-Apr & Varangerfjord (8) & SE/GN & 28 \\
1992 & Apr & East Ice (2) & CS & 232 \\
1992 & Oct & East of Svalbard (7) & SE & 34 \\
1993 & Feb & Southeastern Barents Sea (3) & SE & 24 \\
1994 & May & White Sea (1) & SE & 42 \\
Total & & & & 536 \\
\hline
\end{tabular}

lost blood following the killing by shooting and subsequent bleeding of the seals.

Standard body length $(L)$ of all seals were measured to the nearest $\mathrm{cm}$ in a straight line from the tip of snout to the tip of tail, with the animal lying on its back. Axillary girth $(G)$ was measured to the nearest $\mathrm{cm}$ (see Anon. 1967). Ventral blubber thickness between the front flippers (in a knife-cut on the sternum) and dorsal blubber thickness (d) (in a knife-cut at the mid-line between the front flippers) were measured (excluding the thickness of the skin) to the nearest $\mathrm{mm}$.

During the commercial sealing in the East Ice in April 1992, all measurements were recorded after draining out the blood by first cutting ventrally along a mid-line from the lower jaw to behind the front flippers and then cutting over the bloodvessels to the flippers. The girth measurements may have been slightly biased due to this operation. During these commercial catch samplings, and also during the research cruise in June 1991, dorsal blubber thickness was measured after animals were skinned, in a knife-cut through the blubber layer against the inside of the skin, which may have introduced errors in these measurements compared with other periods.

\section{Data analyses}

Dorsal blubber thickness was tested for possible differences between sexes within all periods. Also a possible relationship between blubber thickness and standard body length was tested. The mean dorsal and ventral blubber thicknesses were compared between different seasons for all seals collected in the period 1990-94. Blubber thickness data from the seals taken in February and June 1988 were compared with similar data from animals collected in February 1993 and June 1991.

$$
\begin{aligned}
& \text { A condition index }(C) \text { expressed as } \\
& C=\sqrt{L / W} \times d \quad(\text { Ryg et al., 1990) }
\end{aligned}
$$

was used to evaluate the seasonal variation in the condition of the animals. In order to calculate condition for the animals in the May 1994 sample (Table 1), where total body weights were lacking, the correlation between a volume index $(V)$ and body weight was calculated on the basis of data from April 1992 and June 1991. Data from these periods were chosen because the condition of the seals were supposed to be most equal to the condition of animals taken in May 1994. The measurements from May 1994 were used to calculate the volume index expressed as

$$
V=L^{2} \times G \times 10^{-5}
$$

The index $C$ was tested for possible differences between the sexes for all periods. Correlations between $C$ and standard body length in the various sampling periods were also tested.

The correlations between $C$ and two other commonly used body condition indices were tested. These indices were, respectively, $G \times 100 / L$ (previously used for harp seals, see Smirnov, 1924) and 


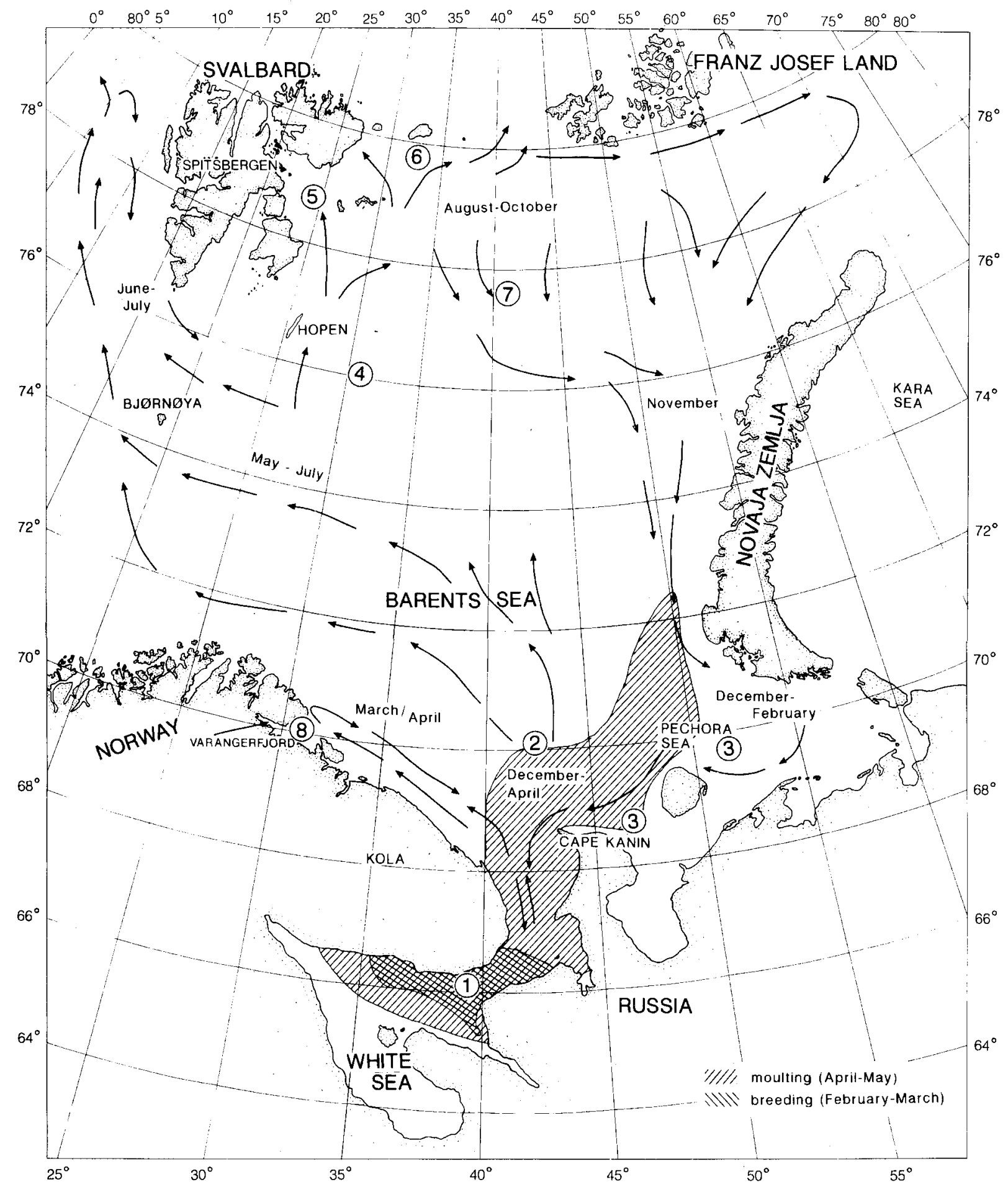

Fig. 1. Map showing the annual migration pattern of Barents Sea harp seals, including the sampling areas (in relation to Table 1) of harp seals in the period 1988-94 (from Nilssen, 1995). 
$K=W / L$ (commonly used in fish studies, see Le Cren, 1951). Also a possible relationship between blubber thickness and standard body length was tested.

The relationship between standard body length and total body weight was tested and compared between June 1991, when the animals were leanest, and October 1992, when the seals were observed to be fattest. Least squares linear regression analyses was used to find the relationship between various parameters. Various differences were tested using student's t-test.

\section{Results}

\section{Blubber thickness}

No correlation was observed between dorsal or ventral blubber thickness and body length in the seals in any of the sampling periods. No difference was observed in dorsal blubber thickness between the sexes in the different periods, except in the April 1992 sample where females were significantly thinner $(t=4.08, n=259, p<0.001)$ than males.

The variation in dorsal and ventral blubber thickness (both sexes pooled, disregarding the difference in dorsal blubber thickness observed in April 1992) within the various seasons in the period 1990-94 are shown in Fig. 2. The dorsal blubber varied more than the ventral blubber in thickness, but both parameters were lowest in spring and early summer with mean values lower than $20 \mathrm{~mm}$ in June 1991. The blubber increased during the summer, and the seals were very fat in September and October,

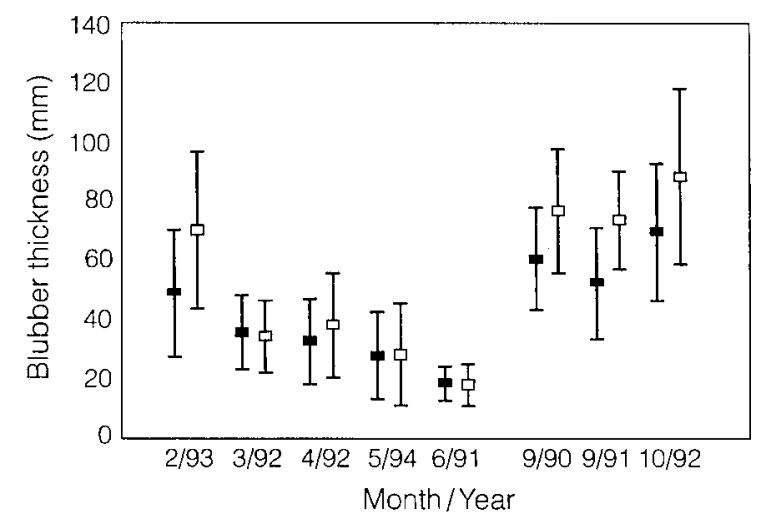

Fig. 2. Seasonal variation in ventral (ם) and dorsal ( $\square$ ) blubber thickness (mean $\pm 95 \% \mathrm{CI}$ ) in adult harp seals (both sexes pooled) collected in the Barents and White Sea in 1990-94. with a mean dorsal blubber thickness of approximately $88 \mathrm{~mm}$ in October 1992. In this period the maximal dorsal blubber thickness was $116 \mathrm{~mm}$ for a 14 years old male with standard body length 183 $\mathrm{cm}$ and weight $189 \mathrm{~kg}$. The energy stored as blubber during the summer and autumn was maintained until February, whereafter the thickness rapidly decreased during the breeding period (late February to mid-March). The blubber thickness seems to be relatively constant in the period between lactation and moult, since no differences in blubber thickness were observed between March and April. The stores of blubber decreased during moult (April-May) to the very low levels observed in June 1991.

Mean ventral blubber thickness was significantly lower $(t=6.66, n=84, p<0.001)$ in harp seals invading the North Norwegian coast in February $1988(\bar{X}=33.3 \mathrm{~mm}$; SE: 8.1), when compared with that from seals captured in the "East Ice" in February 1993 ( $\bar{X}=49.7 \mathrm{~mm}$; $S E$ : 10.9). No significant difference in blubber thickness was observed, however, between seals taken during the invasions in June 1988 ( $\bar{X}=18.7 \mathrm{~mm} ; S E: 3.6)$ and seals sampled in the Barents Sea in June 1991 ( $\bar{X}=$ $18.6 \mathrm{~mm} ; S E: 3)$.

\section{Condition indices}

The regression between the volume index and the body weight in the April 1992 and June 1991 materials was:

$$
W=4.5+3.0 \times V
$$

The body weight was significantly $\left(r^{2}=0.82\right.$, $p<0.001$ ) correlated to the volume index (including both sexes) (Fig. 3).

Correlating the $G \times 100 / L$ (Smirnov, 1924) index with $C$ in all sampling periods from 1990 to 1993 (Fig. 4) a linear regression $\left(r^{2}=0.63, p<0.001\right)$ was obtained:

$$
C=-0.08+0.002 \times G \times 110 / L
$$

The regression analyses of the relationship between $K$, where $K=W \times 10^{5} / L^{3}$ (Le Cren, 1951) and $C$ in all samples in the period 1990-93 (Fig. 5) was also significant $\left(r^{2}=0.59, p<0.001\right)$, yielding a linear regression:

$$
C=-0.02+0.033 \times K
$$

The exponent of $L$ used in the $K$-formula was estimated to be 3.06 based on our data, i.e. very close to the value 3 used by Le Cren (1951). 


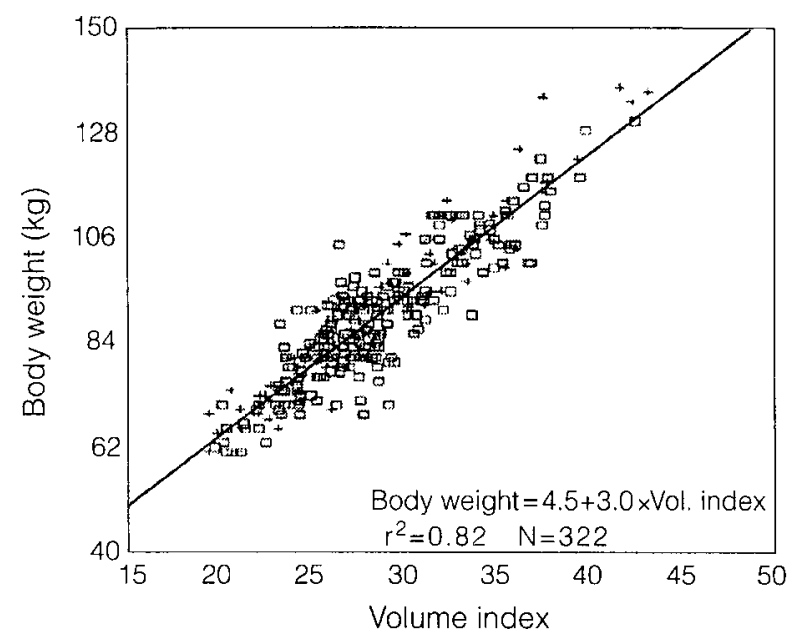

Fig. 3. Total body weight plotted against the volumeindex $(V)$ for adult harp seals collected in the "East Ice" area in April 1992 and southeast of Hopen in June 1991. $V=L^{2} \times G \times 10^{-5}$, where $L$ is standard body length $(\mathrm{cm})$ and $G$ is axillary girth (cm). Males (+) and females ( $\square)$.

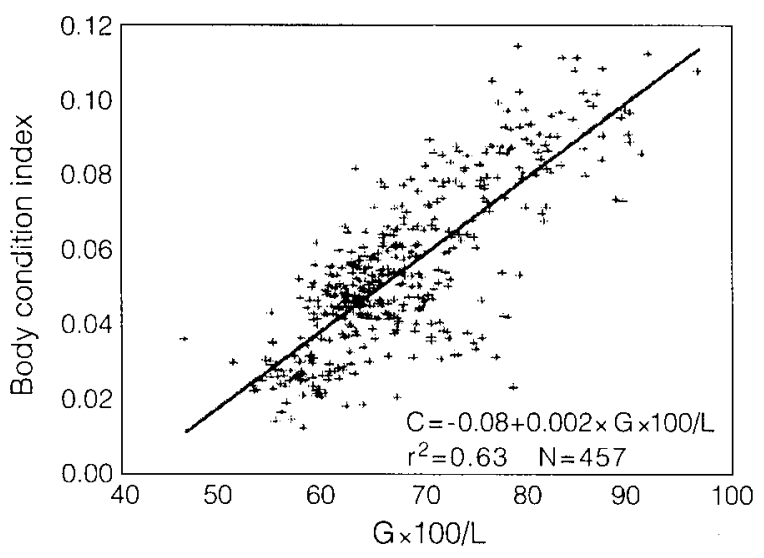

Fig. 4. The body condition index (C) (Ryg et al., 1990) plotted against $G \times 100 / L$ (Smirnov, 1924) for all seals (both sexes pooled) sampled in the Barents Sea in the period 1990-93. $G$ is axillary girth $(\mathrm{cm})$ and $L$ is standard body length $(\mathrm{cm})$.

No correlation was observed between $C$ and body length in the seals in any of the sampling periods. No significant difference in body condition (C) was observed between sexes in the various sampling periods in 1990-94, except for April 1992, where the body condition of the females was significantly lower than for the males $(t=3.58, n=$ $259, p<0.001)$.

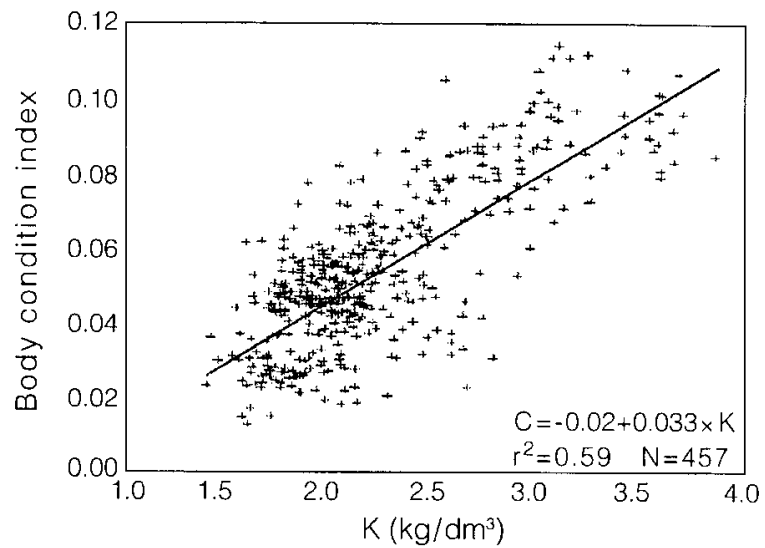

Fig. 5. The body condition index (C) (Ryg et al., 1990) plotted against $K=W \times 10^{5} / L^{3}$ (Le Cren, 1951) for all seals (both sexes pooled) sampled in the Barents Sea in the period 1990-93. $W$ is total body mass $(\mathrm{kg})$ and $L$ is standard body length $(\mathrm{cm})$.

The seasonal variation in the index $C$ of the harp seals sampled in the period 1990-94 is shown in Fig. 6, where data from both sexes are pooled. In the spring period, March-June, the mean condition index was significantly lower $(p<0.001)$ than in the autumn and winter period (September-February). Within the spring season, all recorded indices were significantly different from the mean index for this period $(P<0.001)$, except for March 1992. During the autumn-winter season, however, none of the recorded indices differs significantly from the mean index for this period.

\section{Seasonal increase in body mass}

To evaluate the potential increase in body mass between the extremes in late spring and fall (Fig. 2 and 6), the relationship between length and weight was calculated for June 1991 and October 1992 (Fig. 7). In order to obtain comparable data, only animals longer than $157 \mathrm{~cm}$ were used in this particular calculation. The obtained regression equations were:

$$
\begin{gathered}
\text { June 1991: } \ln (W)=-6.24+2.08 \times \ln (L) \\
\text { October 1992: } \ln (W)=-5.90+2.13 \times \ln (L)
\end{gathered}
$$

No significant difference was found between June and October for the regression coefficients, which indicate that the increase in weight during the summer-autumn period was relatively similar for all animals longer than $157 \mathrm{~cm}$. The increase in weight of a $165 \mathrm{~cm}$ long seal (mean length for all 


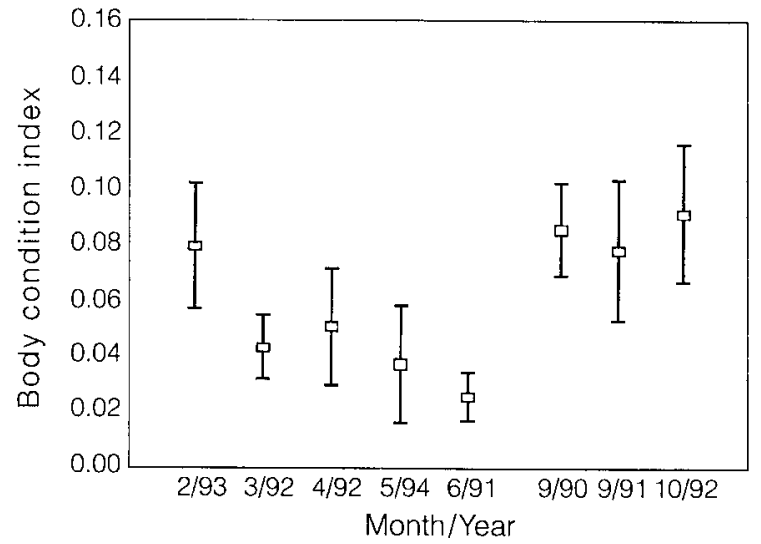

Fig. 6. Seasonal variation in the condition index (C) (Ryg et al., 1990) (mean $\pm 95 \% \mathrm{CI})$ in adult harp seals (both sexes pooled) collected in the Barents and White Sea in 1990-94.

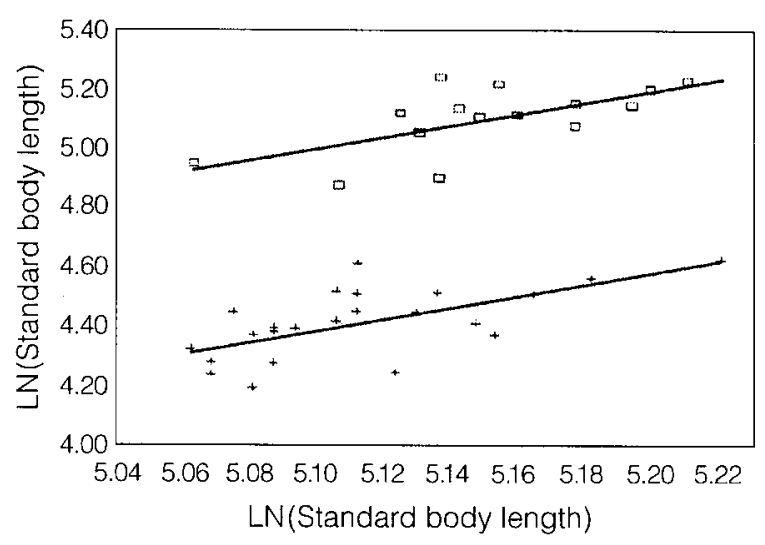

Fig. 7. Variation in total body weight $(\mathrm{kg})$ in adult harp seals $(157 \mathrm{~cm}$ and longer and both sexes pooled) between June $1991(+)$ and October $1992(\square)$.

seals used in this particular calculation) from June $(79.8 \mathrm{~kg})$ to October $(144.8 \mathrm{~kg})$ was $81.4 \%(65 \mathrm{~kg})$.

\section{Discussion}

The observed relationship between $C$ (Ryg et $a l ., 1990)$ and the two other body condition indices used in this study (Smirnov, 1924; Le Cren, 1951) suggest that all these can be used to evaluate variations in body condition of harp seals. It has been shown that $C$ may vary with the body length of harp seals (Chabot et al., MS 1995). However, seals longer than $150 \mathrm{~cm}$, which was used in this study, showed no correlation between $C$ and body length in any of the sampling periods.
The analyses of body condition, using both condition indices and blubber thickness measurements, in this study suggest that Barents Sea harp seals are generally in poor condition in spring and early summer (May-June), condition improves during the course of summer, and seals are in good condition in September-October (Fig. 2 and 6). The energy stores built up during the summer and autumn are maintained until February, but then the seals become thinner as the stores of blubber decrease rapidly during the breeding period (late Februaryearly March). There may be a slight, but not significant, increase in condition (Fig. 6) in the short period between lactation and moult (late March-early April), but the stores of blubber again decrease during moult, which occurs from late April to June (Fig. 2 and 6). The present March-April observations agree with earlier studies of Barents Sea harp seal condition, which suggest that the adult females had a short feeding period between lactation and moult (March-April), as implied by an observed increase in blubber thickness (Sivertsen, 1941).

The observed increase in condition between mid-June and September, and a further increase to October, indicate that summer and autumn must be a very intensive feeding period. The apparent stability in condition during late autumn and early winter suggests that the seals are able to consume sufficient prey to meet energy requirements during this period. The very poor condition observed in both sexes in March and June provide clear indications that feeding by the adult seals must be restricted during breeding and moult (Fig. 6).

The results in this study are consistent with observations made in Northwest Atlantic harp seals where the stores of blubber varied substantially through the year (Sergeant, 1973; 1991; Stewart and Lavigne, 1984; Kovacs et al., 1991). In Northwest Atlantic harp seals fatness increased in late winter, fell during whelping and again during moult, and the seals were still in very lean body condition during the summer. The animals increased in body condition during late summer and by December they were fat. Adult males showed a steady fatness from December to late February, while adult females appeared still to increase in condition until late February. The fall in condition of adult females during lactation, was followed by a short period of intensive feeding in early April before the loss in fatness during the moult. 
The increase in body condition during the course of summer seemed to be lower in harp seals in the Northwest Atlantic than in the Barents Sea. Observations in this study also suggest that adult Barents Sea harp seals reached their maximal condition level earlier in the autumn (probably in October) than in the Northwest Atlantic (February) (Chabot et al., MS 1995).

Seasonal variations in body mass, blubber thickness, condition index and energy consumption have been observed in both subadult and adult captive harp seals, but with substantial variations among individual animals (Renouf et al., 1993). Lager et al. (1994) also reported that food intake in captive subadult harp seals was generally low during moult (May-June), to be followed by a pronounced increase in feeding in the period JulyOctober. During the period October-April the food intake of captive seals was observed to be relatively stable.

During the extensive harp seal invasions to the coast of North Norway in 1986-88 the invading harp seals, particularly the subadults, were said to be thin and in poor condition (Wiig, 1988; Øritsland, 1990). Adult seals taken as bycatches in gill nets at the North Norwegian coast in February 1988 confirm this by having sacrificed parts of their blubber storage and being significantly thinner than animals taken in the southeastern Barents Sea in February 1993. By the end of the annual reduced feeding period, however, no significant differences were observed in blubber thickness between adult seals taken in June 1988 at the coast of North Norway and seals taken southeast of Hopen in June 1991.

\section{Acknowledgements}

Thanks are due to the crews and field assistants on board the vessels Johan Ruud, Polarfangst, Michael Sars, Selis, Meridian, Melshorn, Jan Mayen and Varzuga. The following field assistants participated during the sampling in Varangerfjord and in the White Sea: A. Ørjebu, T. O. Rudi, S. A. Kjellqwist, G. Henriksen, Y. Nazarenko and V. Adrianov. Thanks are also due to D. Chabot and E. M. Nilssen for comments on the manuscript, and to B. Bergflødt, K. A. Fagerheim, N. E. Skavberg, R. Wolstenholme, F. Strand and L. Olsen for technical assistance. The ecological studies of harp seals were supported by funding from the Norwegian
Council of Research, project no. 4001-701.260 and 108147/110.

\section{References}

ANON. 1967. American Society of Mammalogists. 1967. Standard measurements of seals J. Mammal. 48: 459-462.

MS 1992. Report of the Joint ICES/NAFO Working Group on Harp and Hooded Seals, Copenhagen, 14-18 October 1991. ICES C.M. Doc., No. Assessment: 5, $31 \mathrm{p}$.

MS 1994. Report of the Joint ICES/NAFO Working Group on Harp and Hooded Seals, Copenhagen, 15-21 September 1993. ICES C. M. Doc., No. Assessment: 5, $35 \mathrm{p}$.

BECK, G. G., T. G. SMITH, and M.O. HAMMILL. 1993. Evaluation of body condition in the Northwest Atlantic harp seal (Phoca groenlandica). Can. J. Fish. Aquat. Sci., 50: 1372-1381.

BENJAMINSEN, T. 1979. Pup production and sustainable yield of White Sea harp seals. Fiskeridir. Skr. Havunders, 16: 551-559.

BOGSTAD, B., K. H. HAUGE, and $\varnothing$. ULLTANG. MS 1995. Results of simulation studies using a multispecies model for the Barents Sea (MULTSPEC). Int. Whal. Comm., SC/47/NA1, 33 p.

CHABOT, D., G. B. STENSON, and N.B. CADIGAN. MS 1995. Short- and long-term fluctuations in the size and condition of harp seal (Phoca groenlandica) in the Northwest Atlantic. NAFO SCR Doc., No. 42, Serial No. N2551, 27 p.

FEDAK, M. A., and S. S. ANDERSEN. 1987. Estimating the energy requirements of seals from weight changes. In: Marine mammal energetics, A.C. Huntley, D.P. Costa, G. A. J. Worthy and M. A. Castellini (eds), Society for Marine Mammalogy, Lawrence, KS. p. 206-226.

HAUG, T., A. B. KRØYER, K. T. NILSSEN, K. I. UGLAND, and P. E. ASPHOLM. 1991. Harp seal (Phoca groenlandica) invasions in Norwegian coastal waters: age composition and feeding habits. ICES J. Mar. Sci., 48: 363-371.

HAUG, T., K. T. NILSSEN, N. ØIEN, and V. POTELOV. 1994. Seasonal distribution of harp seals (Phoca groenlandica) in the Barents Sea. Polar Res., 13(2): 163-172.

KJELLQWIST, S. A., T. HAUG, and T. ØRITSLAND. 1995. Trends in age composition, growth and reproductive parameters of Barents Sea harp seals Phoca groenlandica. ICES J. Mar. Sci., 52: 197-208.

KOVACS, K. M., D. M. LAVIGNE, and S. INNES. 1991. Mass transfer efficiency between harp seal (Phoca groenlandica) mothers and their pups during lactation. J. Zool., Lond., 223: 213-221.

LAGER, A. R., E. S. NORDØY, and A. S. BLIX. 1994. Seasonal changes in food intake of harp seals (Phoca groenlandica) at $69^{\circ}$ N. Mar. Mamm. Sci., 10(3): 
$332-341$.

Le CREN, E. D. 1951. The length-weight relationship and seasonal cycle in gonad weight and condition in the perch (Perca fluviatilis). J. Anim. Ecol., 20: 201-219.

LOCKYER, C. 1986. Body fat condition in northeast Atlantic fin whales, Balaenoptera physalus, and its relationship with reproduction and food resource. Can. J. Fish. Aquat. Sci., 43: 142-147.

LYDERSEN, C., L. A. ANGANTYR, Ø. WIIG, and T. ØRITSLAND. 1991. Feeding habits of northeast Atlantic harp seals Phoca groenlandica along the summer ice edge of the Barents Sea. Can. J. Fish. Aquat. Sci., 48: 2180-2183.

NILSSEN, K. T. 1995. Seasonal distribution, condition and feeding habits of Barents Sea harp seals (Phoca groenlandica). A. Blix, L. Walløe, and Ø.Ulltang, (eds.). In: Whales, seals, fish and man. Elsevier Science B.V., p. 241-254.

NILSSEN, K. T., P. GROTNES, and T. HAUG. 1992. The effect of invading harp seals (Phoca groenlandica) on local coastal fish stocks in North Norway. Fish. Res., 13: 25-37.

NILSSEN, K. T., I. AHLQUIST, J-E. EliASSEN, T. HAUG, and L. LINDBLOM. MS 1994. Studies of food availability and diets of harp seals (Phoca groenlandica) in the southeastern Barents Sea in February 1993. ICES C. M. Doc., N:12, 24 p.

NILSSEN, K. T., T. HAUG, V. POTELOV, V. A. STASENKOV, and Y. K. TIMOSHENKO. 1995a. Food habits of harp seals (Phoca groenlandica) during lactation and moult in March-May in the southern Barents Sea and White Sea. ICES. J. Mar. Sci., 52: 33-41.

NILSSEN, K. T., T. HAUG, V. POTELOV, and Y. K. TIMOSHENKO 1995b. Feeding habits of harp seals (Phoca groenlandica) during early summer and autumn in the northern Barents Sea. Polar Biol., 15: 485-493.

ØRITSLAND, T. 1990. Seals in the northeast Atlantic and interactions with fisheries. Comm. Arc. Int. Commnt., 2: 10-13.

PITCHER, K. W. 1986. Variation in blubber thickness of harbour seals in southern Alaska. J. Wildl. Manage., 50: 463-466.

POND, C. M. 1978. Morphological aspects and ecological and mechanical consequences of fat deposition in wild vertebrates. Annu. Rev. Ecol. Syst., 9: 519570.

READ, A. J. 1990. Estimation of body condition in harbour porpoises, Phocaena phocaena. Can. J. Zool.,
68: $1962-1966$

RENOUF, D., R. GALES, and E. NOSEWORTHY. 1993. Seasonal variation in energy intake and condition of harp seals: Is there a harp seal morph? Problems for bioenergetic modelling. J. Zool., Lond., 230: 513-528.

RYG, M., C. LYDERSEN, N. H. MARKUSSEN, T. G. SMITH, and N. A. ØRITSLAND. 1990. Estimating the blubber content of phocid seals. Can. J. Fish. Aquat. Sci., 47: 1223-1227.

RYG, M., T. G. SMITH, and N.A. ØRITSLAND. 1988. Thermal significance of the topographical distribution of blubber in ringed seals (Phoca hispida). Can. J. Fish. Aquat. Sci., 45: 985-992.

SCHOLANDER, P. F., V. WALTERS, R. HOCK, and L. IRVING. 1950. Body insulation of some arctic and tropical mammals and birds. Bull. Mar. Biol. Lab. Woods Hole, 99:225-236.

SERGEANT, D. E. 1973. Feeding, growth and productivity of northwest Atlantic harp seals (Pagophilus groenlandicus). J. Fish. Res. Board. Can., 30: 1729.

SERGEANT, D. E. 1991. Harp seals, man and ice. Can. Spec. Publ. Fish. Aquat. Sci., 114, 153 p.

SIVERTSEN, E. 1941. On the biology of the harp seal Phoca groenlandica Erxl. Investigations carried out in the White Sea 1925-1937. Hvalrådets Skr.: 1166.

SMIRNOV, N. 1924. On the eastern harp seals Phoca (pagophoca) groenlandica var. oceanica Lepechin. Troms $\phi$ Mus. Arsh., 47(2): 1-11.

STEWART, R. E. A., and D. M. Lavigne. 1984. Energy transfer and female condition in nursing harp seals Phoca groenlandica. Holarct. Ecol., 7: 182-194.

WIIG, Ø. 1988. Grønlandssel og selinvasjon. Hva vet vi - hva tror vi. Naturen, 1988(2): 35-41.

WORTHY, G. A. J. 1987. Metabolism and growth of young harp and grey seals. Can. J. Zool. , 65: 13771382.

WORTHY, G. A. J., and D. M. LAVIGNE. $1983 \mathrm{a}$. Energetics of fasting and subsequent growth in weaned harp seal pups, Phoca groenlandica. Can. J. Zool., 61: 447-456.

WORTHY, G. A. J., and D. M. LAVIGNE. 1983b. Changes in energy stores during postnatal development of harp seals, Phoca groenlandica. J. Mammal., 64: 89-96.

WORTHY, G. A. J., and D. M. LAVIGNE. 1987. Mass loss, metabolic rate, energy utilization by harp and grey seal pups during the postweaning fast. Physiol. Zool., 60: 352-364. 